\title{
フランスの医薬品監視システムについて
}

\author{
野嶋 豊*1，真山武志*2，福島 宏*3，楠 正*4
}

\section{On French Pharmacovigilance System}

\author{
Yutaka NOJIMA*1, Takeshi MAYAMA*2, Hiroshi FUKUSHIMA*3, Tadashi KUSUNOKI*4 \\ ${ }^{* 1}$ Medical Advisor, Nippon Hoechst Marion Roussel Ltd. \\ 2-17-51 Akasaka, Minato-ku, Tokyo 107, Japan \\ *2 Pharmaceutical Information Center, Meiji Seika Kaisha, Ltd. \\ ${ }^{* 3}$ Post Marketing Surveillance I, Fujisawa Pharmaceutical Co. Ltd. \\ *4 Japanese Society for Pharmacoepidemiology
}

\begin{abstract}
〈Abstract〉
Spontaneous reporting system of adverse reactions (ADRs) is indispensable to secure drug safety. Although good systems of western countries are well-known in Japan, it seems that the French pharmacovigilance system is not familiar, as compared with the yellow-card system in the UK and the MEDWatch program in the US.

This report outlines various features of the French system according to our information collected by a visit to the French medicines agency and one of the regional centers. The "good pharmacovigilance practices," enforced by the agency in 1995, is used as a reference.

Notable features are summarized as follows:(1) decentralized activities by the 31 regional centers collecting spontaneous ADR reports from healthcare professionals, (2) centralized EDP-system retaining ADR data, (3) official decision-making process called "inquiry", which opens when a signal of safety issues comes up, and synthesizes a consensus and proposal on necessary measures, (4) bidirectional communication between the regional centers and prescribers, reporting ADRs and providing safety information by $\mathrm{Q} \& \mathrm{~A}$, (5) collaboration of specialist committees and pharmaceutical companies with the above elements, and so forth.

The system is characterized by these elements constructing collectively an effctive system to prevent ADRs and reduce the seriousness. These findings will be helpful, even in Japan, when subjects for improvement of a reporting system are discussed.
\end{abstract}

Key words : pharmacovigilance, post-marketing surveillance, spontaneous reporting, adverse reaction

\section{はじめに}

医薬品による副作用，とくに重篤な副作用を防 ぐためには，早期に発見すること，迅速に因果性
と重篤度を評価して医療社会に伝達すること, 適 切な対策をとることなどが必要である.

クロラムフェニコールによる再生不良性貧血, サリドマイドによる新生児四肢の先天性奇形が最

${ }^{* 1}$ 日本へキスト・マリオン・ルセル株式会社 研究開発本部メディカルアドバイザー T 107 東京都港区赤坂 2-17-51

$* 2$ 明治製菓株式会社 医薬情報センター

${ }^{* 4}$ 連絡先: 日本薬剤疫学研究会 
初に報告されたのは 1950 年 ${ }^{1)}$ おる゙ 1961 年 ${ }^{2)}$ あったが，いずれも観察した医師による専門誌へ の自発的報告であった. 1953 年に米国医師会は全 米の医師に血液疾患の症例を医師会またはFDA に報告するように求めたが3)，これは後にサリド マイド事件を契機としてしだいに各国で確立され た自発報告制度の原型となった。観察した医療従 事者が感じた問題は「シグナル」となり報告の集 積はその増強となるから, 迅速にシグナルをとら えるため，しかるべき機関に情報を集める公共の 制度は再発防止に有効かつ不可欠である. 医薬品 も国際化時代を迎えて情報システムは整備され, 現在では有害事象・副作用の報告は各国から WHO の国際モニタリング協力センターに集中さ れるようになっているが4)，さらに情報を評価し て注意を喚起するプロセスが必要である. 因果性 を解明するためには集団傾向分析や分析疫学的方 法を用いるが，長期間と数々の困難を伴う場合が 多く, 解明に至らないとしても適時に適切な対策 をとることが大切である.

日本では報告率を高めることが課題となってお $\eta^{5)}$, 各国にも制度を改善する努力がみられる. 米 国で 1993 年に始まったプログラム“MEDWatch” の名称は医薬品を監視する意味をよく表し, 英国 の “Yellow-Card System”とともに日本でもよ く紹介されている6,7).これらに比しフランスの “Pharmacovigilance System” はあまり知られて いないと思われるが，地域分散型で収集する有害 事象の症例を中央に集中して評価する優れた特徵 をもつとされている.我々は, 日本の RAD-AR 協 議会の調査団として昨年このシステムを見学する 機会を得たので，知りえた内容を報告して日本の システムの将来を考える参考に供したい. 調査団 は, 真山武志 (明治製菓), 福島宏 (藤沢薬品工業), 野嶋豊（日本へキスト・マリオン・ルセル）で構 成し, 楠正が随行した。

“Pharmacovigilance” は「医薬品監視」と訳す ことができよう。フランスでは伝統的に PMS (Post-Marketing Surveillance : 市販後調查) と ほほ同義に用いられているが，主として有害事 象・副作用の監視を表すと考えられる。最近では
欧州連合（European Union：EU）の公用語にな り, 英語としても使われるが, 以下では PV と略 す. “Surveillance”も「監視」を意味するので, PMS は「市販後監視」と訳すこともでき, PV と PMS の区別は難しい. “Pharmacovigilance System” はフランスのシステムの固有名であり, こ れを「医薬品監視システム」として本論のタイト ルに用いた. 後述のように, 本システムはある医 薬品の安全性が問題となるときには有効性・有益 性とのバランスを考慮して対策を立てるので, 有 効性を全く無視するわけではないが, 有効性を評 価するシステムではない.一方, PMS は市販後に 行われる有効性評価の研究を含むと考えられる。

フランスでは医薬品庁 (Medicines Agency) が 新薬の承認, GMP, GLP, GCP などに関連する医 薬品行政を統括し, 最近パリ市郊外に移設された とのことであるが, PV システムの中心もここに ある. 調査団は 1996 年 8 月 22 日の午前中にパリ 市内 Brossais 大学病院臨床薬理部門内の地区セ ンター (Regional Pharmacovigilance Centre), 午後は医薬品庁を訪問した。地区センターの出席 者はDr. Carmen Kreft Jais と Dr. Nicolas Uhart, 医薬品庁の出席者は Dr. Morin Michele であった，医薬品庁は，医薬品に関する EU の新 規制が発効する予定の 1995 年 1 月に合わせ, 日本 の市販後調查に関する基準 (Good PostMarketing Surveillance Practice : GPMSP) に あたる PV の基準として “Good Pharmacovigilance Practices”を 1994 年 12 月に制定したが8), ここではこの PV 基準と 1995 年 3 月に制定され た PV に関する法律（Decree No.95-278，以下 Decree $)^{9)}$ ，およびその他の資料と説明内容に基づ いてこのシステムの概要を説明する，資料はすべ て提供された英訳版を用いた，図表も資料から選 択したが，理解を助けるために一部で微修正を加 えた。

\section{システムの概要}

フランス全土を分割した 31 の地区に 31 の地区 センターがある. 医薬品庁の PV 担当部署 (Agency PV Unit) との協力態勢 (Coordination 
of regional PV centers: CRPV) は Fig. 1 のと おりであり，医療従事者および医薬品市販承認保 持者 (Marketing Authorization Holder : MAH, 以下企業と略す）と密接な関係を持つ形で有害事 象の報告と評価，およびその他の情報交流を行っ ている。医療従事者による報告は地区センターか ら中央の PV Unitに集中される。データを評価 し，問題が発生したときに対策を立てるために “Technical Committee” および “National Commission of Pharmacovigilance” が設置されてお り, 以下ではそれぞれ技術委員会, PV 委員会と略 す。問題発生時の総合的評価と対策検討を「審查 (inquiry)」といい，これら委員会が重要な役割を 果たす。

地域と中央との関係は双方向的であり, 集中し たデータは要求があれば地区センターを通して医 療従事者に提供される。たとえば医薬品名と副作 用名を指定すると地区の端末から全国の症例を検 索できる，患者からの問合せにも答えるが，地区 センターからの情報提供は常に処方医を通して行 われる. 企業も双方向的に関係し, 市販後医薬品 について有害事象の報告義務をもつ一方で，地区 センターに報告された重篤症例は迅速に企業に伝 達される. 企業は審査にも協力する.

\section{システムの構成と役割}

$\mathrm{PV}$ システムは, 医薬品庁, 地区センター, PV 委員会, 技術委員会, 医療従事者および企業によっ て構成されており，それぞれ次のような構成と役 割をもっている.

\section{1. 医薬品庁およびその PV Unit}

医薬品庁は全国で行われるすべての PV 活動を 支援して統合する．PV Unit は地区センターから 情報を収集し，計算機システム“Pharmacovigilance Case Report Data Base” として維持す る. 1995 年までと 1995 年以降の状況は Fig. 2 に 対比されるが，集中されたデータはさらに EU の 規制当局 (European Medicines Evaluation Agency：EMEA) の所管部署 (Committee for Proprietary Medicinal Products : CPMP)，およ びスウェーデンのウプサラにあるWHOのセンター
-Reporting

-Evaluation

-Communication

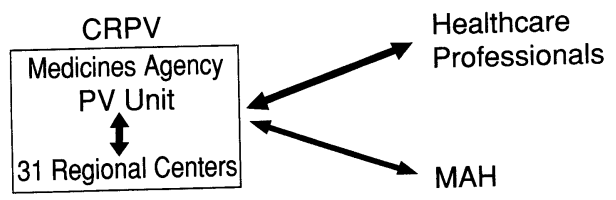

Fig. 1 Management of PV data

\section{Before 1995}

Since 1995

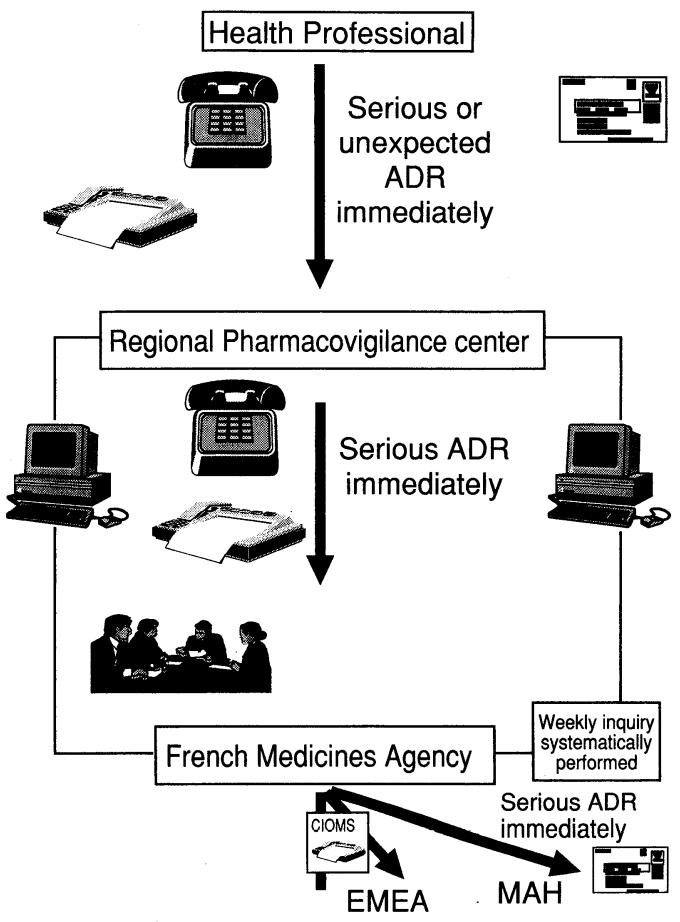

Fig. 2 Data-flow of ADR-reports

に転送され，世界との関係を含む全体像は Fig. 3 に示されている.国外への伝達にはCIOMS (Council for International Organizations of Medical Sciences）の様式 ${ }^{10)}$ が用いられる. 国内 で重篤な事象が発生した場合には，その情報を得 てから 15 日以内に EMEA および関連する国内 


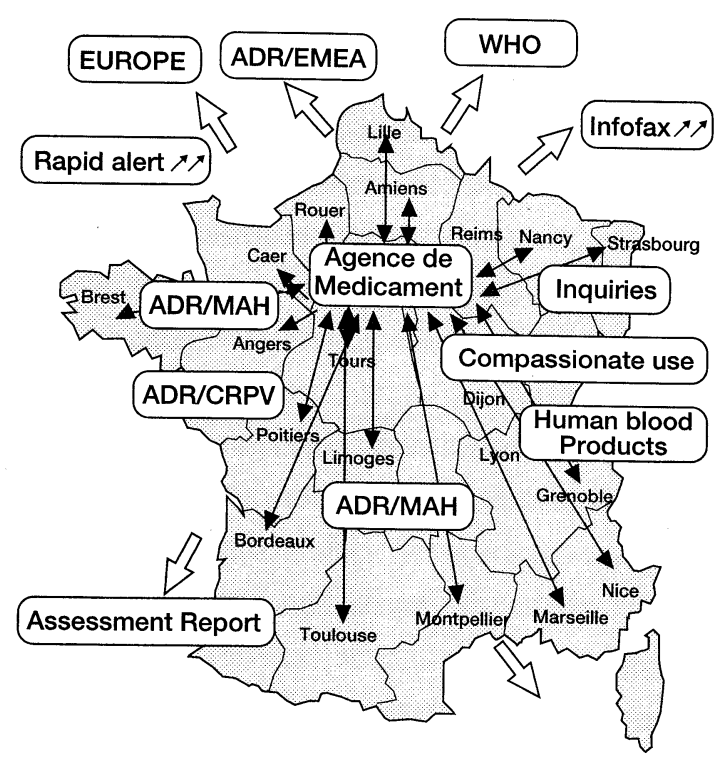

Fig. 3 Overall communication of ADR-data

企業に伝達する，有害事象・副作用に関する情報 は, 国内企業, CPMP, 各国の当局, WHO の協 カセンターなどからも PV Unit に集められる.

PV Unit は, PV 委員会, 技術委員会の会議を 主催して事務局を務め, PV 委員会の審査結果を 医薬品庁の長官（General Director）および厚生 大臣 (Minister of Health) に答申する。専門誌 と一般報道機関に対する情報の開示については医 薬品庁が責任をもつ.

\section{2. 地区センター}

地区センターは, 国立大学病院の薬理学, 臨床 薬理学もしくは臨床毒性学の部門内にあり, 構成 員は医薬品庁の長官と病院側の合意のうえで医師 と薬剤師の中から選ばれる.訪問した Brossais 大 学病院での出席者 Dr. Carmen Kreft Jais は医 師, Dr. Nicolas Uhart は薬剤師であった. 構成員 の $80 \%$ は医師が占め, 薬剤師は $20 \%$ あるが, 給 与は病院から出る. Brossais 大学病院のセンター は人口 250 万人の地域を管轄し，この地域の医師 は 11,000 人, 薬剤師は 3,000 人以上である.

地区センターは，医療従事者だけではなく企業 などいかなる情報源からの報告をも受け付ける. 患者と報告者の氏名は特定の関係者を除いて機密
とし, 原記録との照合, 確認, および必要とされ る補足を行って Fig. 4 に示す所見の様式に記録 する. 使用薬物との因果性の評価には規定の方法 を用い，その結果を報告者に連絡する。これらの 症例データは地区センターに設置されている端末 から全国システムに入力するが, 重篤な症例の報 告を受けた場合には直ちに中央に伝達する、企業 にも同じ症例が報告されている場合があり, 重篤 で未知な有害事象報告の記録をとるにあたっては とくに企業との協力が必要とされている。医療従 事者から有害事象の情報について問合わせがあれ ばこれに答え, 中央から審査にあたっての協力要 請があれば必要な調查・研究を実施する.

\section{3. 医療従事者}

医療従事者とは医師, 歯科医師, 助産婦, 薬剤 師, 看護婦をいう。医薬品の関連が疑われ重篤ま たは予期しない有害事象を観察もしくは見聞した 医療従事者は, 処方・調剤を行ったかどうかには よらず，直ちにこれを地区センターに届け出なけ ればならない. Decree は “must notify” と記載 しており，罰則はないが義務とする点は他国と異 なる特徵であろう. 医師からの届出が $94 \%$ を占め ている，重篤とは致死的または生命に関わる，機 能障害に至る, 入院または入院の延長を要する, などをいい，予期しないとは医薬品の添付文書に 記載のないものをいう点は最近の諸国の定義と変 わらない，医療従事者は報告症例に関する情報・ 原資料を保存し，地区センターが作成する記録の 完成および審査に協力しなければならない.

\section{4. 企業 (MAH)}

企業は PV 部門を設置して有害事象の情報収集 にあたらせ，その責任者名（医師または薬剤師） を医薬品庁に届け出なければならない. 重篤症例 については最新の規制に従った報告の義務（現在 は情報を得てから 15 日以内）がある。すなわち， 規定の方法に従って因果性を評価した結果を報告 者に知らせ, 地区センターが行う評価に協力する など地区センターと同じ (裏返しの) 役割をもち, データおよび原資料を保存する，定期報告も企業 の義務であり, 現在の規制によると市販後初めの 2 年間は 6 カ月ごと, 次の 3 年間は 1 年ごと, そ 


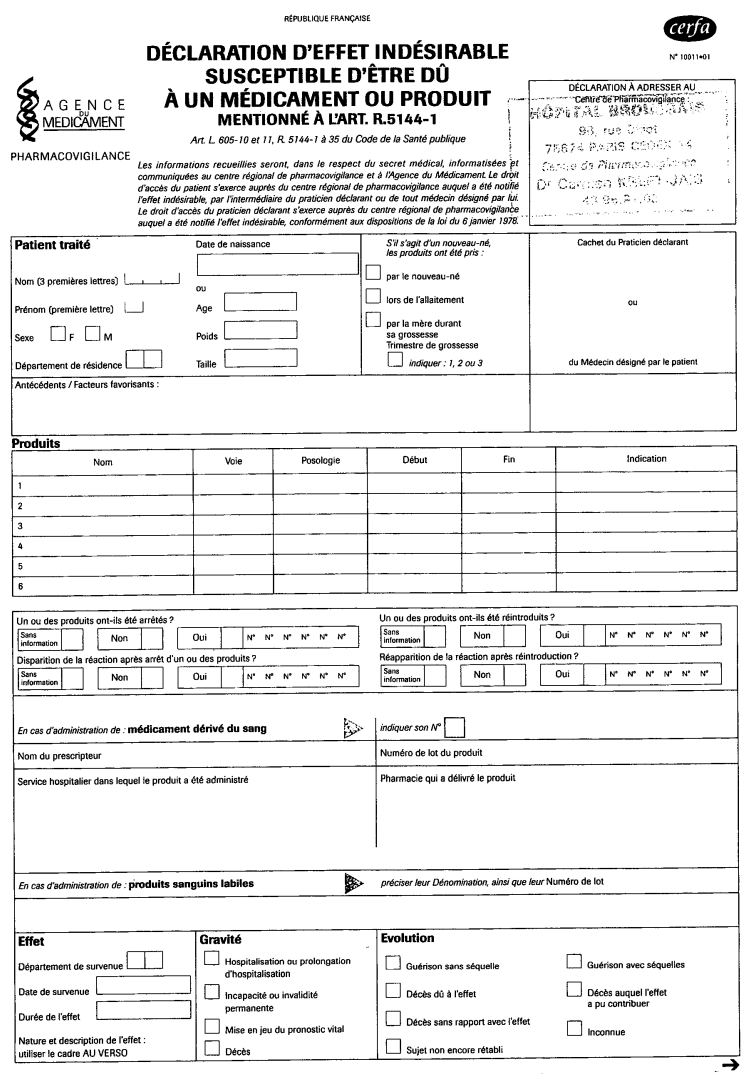

Fig. 4 Suspect ADR report form

の後は 5 年ごとであるが, 臨時の要求に対する準 備も必要である。定期報告の内容は各種副作用の 頻度, リスク因子の研究結果, 重篤事象を避ける 対策, 売上と使用量などであり，審査を要する問 題が発生すればこれらの情報を提出して協力す る. 医薬品の適正な使用, および安全性プロフィー ルに関する情報を医療従事者に提供すべきことは 企業の役割として当然である.

\section{Technical Committee（技術委員会）}

本委員会は各地区センターの代表者 31 名, およ び医療に関連する各領域の権威者と研究機関の代 表者で構成し, 評価・審査にあたっての技術的作 業を担当する. 月 1 回〜隔月に会合してその間の 報告症例をレビューし，11月には年 1 回の特別な 会議を開いて PV 委員会への報告をまとめる. 審 查を要する課題があれば, PV 委員会を通して医

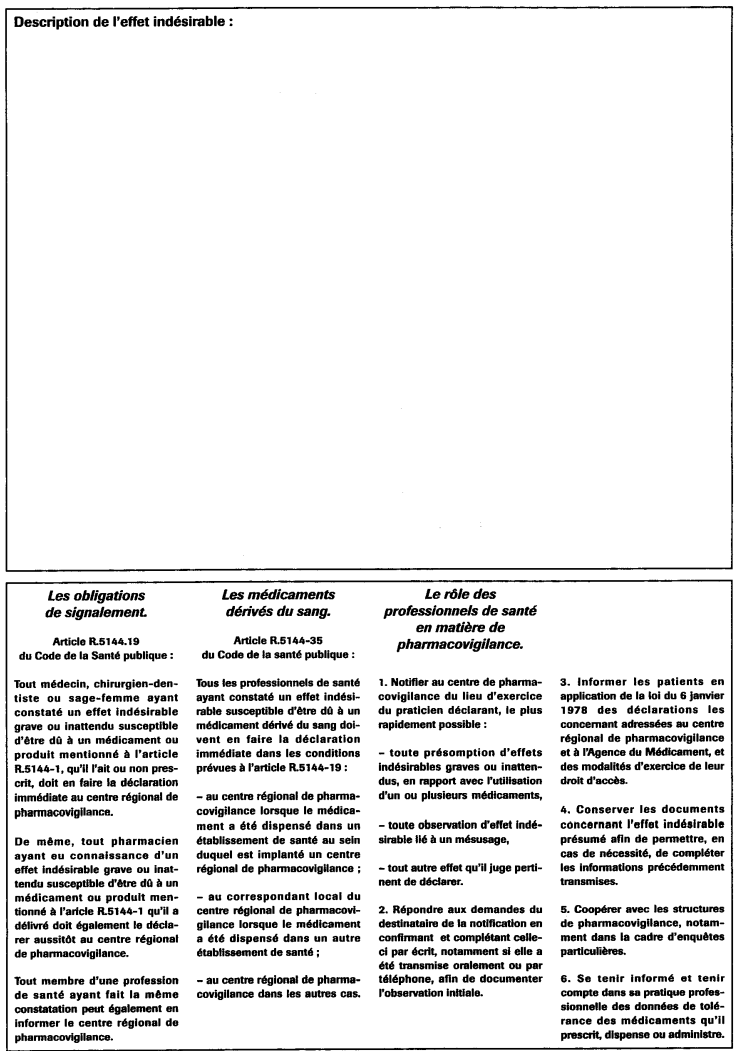

薬品庁の長官に提起する.

6. National Commission of Pharmacovigilance (PV 委員会)

医薬品庁長官と厚生大臣の公的諮問機関（official advisory board）にあたり, 医薬品庁長官, 国立研究所の所長など職によって定まる 4 名と, 厚生大臣が指名する 31 名の医療の専門家で構成 して委員長を選出する. 31 名の専門家には少なく とも 3 名の開業医を含む医師 11 名, 薬理または毒 性学者 10 名, 病院薬剤師 3 名, 開局薬剤師 1 名, 薬剤疫学者 2 名, 企業界を代表する 1 名などを含 み, 任期は 3 年である. 技術委員会の準備に基づ いて行う審査では重要な役割を果たし，とるべき 対策を答申するが, 意志決定は医薬品庁の長官と 厚生大臣の責任で行われる. 


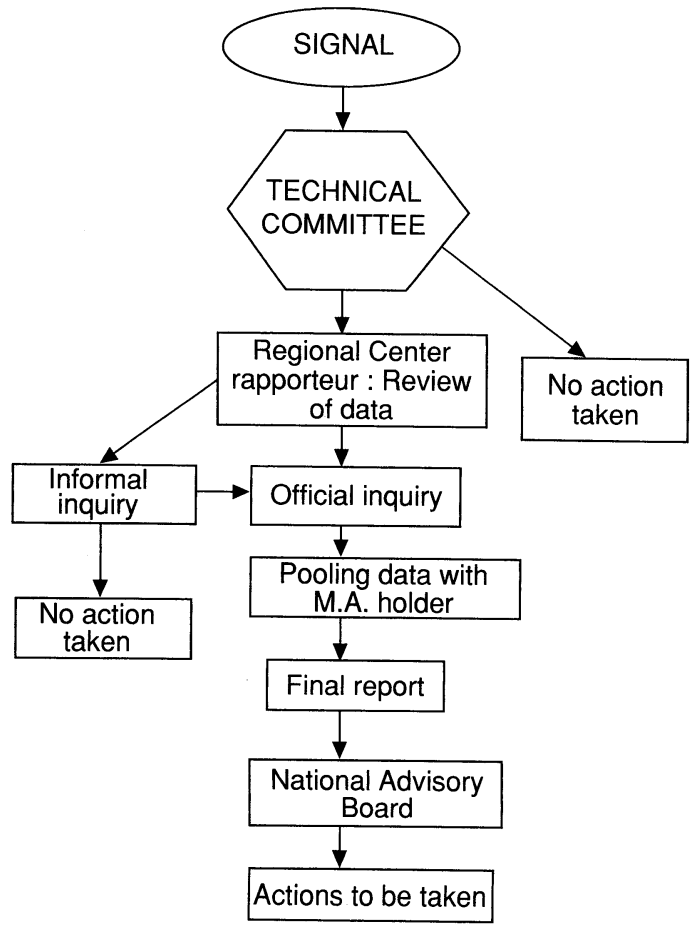

Fig. 5 Pharmacovigilance inquiry process

\section{審査の内容と手順}

ある薬もしくはある種の薬について，多くの同 類の報告が異常に続くと安全性の問題の「シグナ ル」となる. 問題は技術委員会, PV 委員会, もし くは厚生省から提起され, 国外のシグナルにも注 意するが, 医薬品庁長官の判断によって始まる「審 査」は, Fig. 5 の流れに沿って進められる.

初めに長官は, 対象とする医薬品名と有害事象, 審査を行う理由, 審査の責任者などを明らかにし て企業を含む関係者に通知する，責任者は最終報 告書を起草するので “rapporteur”とも呼ばれ, $\mathrm{PV}$ 委員長の推薦に基づいていずれかの地区セン ターから長官が指名するが，同時に報告期限も定 める. 必要なら数名の共同責任者が他の地区セン ターから選ばれ, 企業と責任者との連絡が始まり, 報告症例を検討する会合の日程が決まる。会合は その地区センターまたは医薬品庁で行われる。審 査の範囲, すなわちどの地域のどの期間のデー

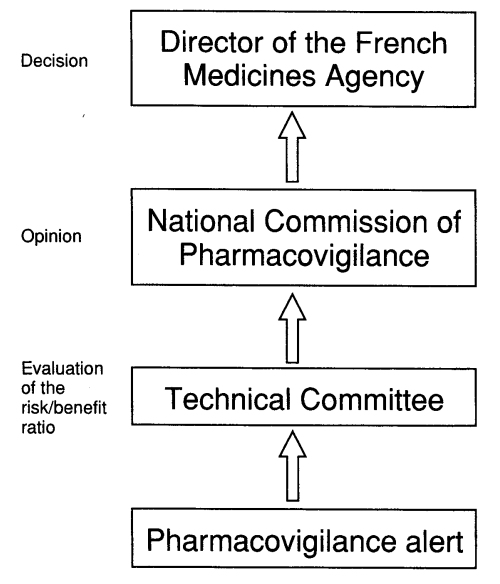

Fig. 6 French decision making process

夕・報告症例を集め, どのように分析するかは第 1 回の会合で決定する。事象の定義, 診断分類法 と必要な検査, 不可逆性の評価法, ほかにありう る原因を除外しつつ因果性を評価する方法などに ついては企業とも協議のうえで確立する.

データの収集には審査を担当する地区センター と企業が協力し，PV データベースと企業がもつ データに重複する症例を省いて必要となるすべて のデータをプールし, 責任者に提出するが, 患者 名と報告者名はマスクされる，因果性を評価する ために責任者と企業はその領域の専門家を 1 数 名リストして協力を求めることができ，医薬品庁 と連絡して決定する。評価には規定の方法を用い, できるだけ合意に基づいて行う。

責任者は審査に必要なその他のデー夕を集める 際に企業の協力を求め, 企業は薬物動態, 毒性な どの前臨床データ, 申請者・市販後の臨床試験結 果, その他の公表報告, 他国での成績, 経年的売 上・使用量 (人年を単位とする) の実績とその地 区別内訳などを提出する。発生率・リスクは因果 性を認めた報告に限定する場合と全報告による場 合について推定し，用量との関係を検討する。さ らに曝露から事象発生までの時間, 重症度と重篤 度, 中止後回復までの時間, 最終の結果, 臨床的 生物学的特性と発生機作, 当該医薬品が投与され た集団の中での報告例の患者特性, ありうるリス 
薬凧疫学 Jpn J Pharmacoepidemiol, 2(2) Oct 1997 : 109

ク因子, 認められる有効性, QOL への影響, あり うる代替薬などについても研究し，可能な限り同 類の他薬もしくは無治療と比較する.

公的報告書は責任者と企業が共同作成して技術 委員会に提出し，技術委員会は審査が適切に行わ れたことを保証する. 報告書は妥当と認められる と PV 委員会に送付されるが，その間に医薬品庁 において審査責任者と企業を含む会合があり，そ れぞれが適切と考える対策について話し合う．報 告書および対策について合意が得られなければ, 企業はその主張を支持するデータを PV 委員会に 提出する. PV 委員会はこれらに基づいて審議し， 委員会としての提案を医薬品庁長官に提出する が, 意志決定は Fig. 6 に示すプロセスに従って長 官と厚生大臣が行う.

\section{公表の基準 (Good Publication Practices) およびその他の事項}

Good Publication Practices は, 有害事象を観 察した医療従事者が専門誌上に報告する，または 学術集会において口頭もしくはポスターで公表す るにあたっての基準である。著者に対しては重篤 または未知の副作用を公表に先立って行政に報告 する, タイトルに医薬品と有害事象の名称を含め る，早期に高品質の公表を準備する，などの基準 を定め, 専門誌の編集者・審査者に対しては重篤 でとくに未知の副作用の公表を急ぎ, 企業が “reply（反論，見解，対策など）”を公表する道を 開く，などの基準を定めている。

以上はもっぱら有害事象・副作用の報告に関す る問題であったが，PV システムは医薬品の監用 と誤用をも報告の対象としている。 その他医薬品 庁および地区センターの役割として重視される事 項には, PV システムに関する教育, PV 活動の理 解を深め広めること, 方法的発展に寄与すること, などがある.医療従事者からの報告数が 1994 年の 14,088 件から 1995 年の 16,283 件に $16 \%$ 増加し たことに連動して，医療従事者から地区センター への質問も 24,350 件から 25,795 件に 6\%増加し ている，企業からの報告も医療従事者からとほほ 同数であるが, かなりの部分が重複している.

\section{むすび}

医薬品による副作用を軽減し発生を防止したい という社会的要請に答えるために自発的報告は欠 かせない. 1995 年の日本の報告数はモニター報告 が 1859 件, 企業報告が 14,288 件, 合計 16,147 件 である.人口 100 万人当たりの報告率として前述 のフランスでの報告数と比較すると, 日本で 129 件フランスで 281 件となり, 日本の報告率は他の 先進国に比べても低水準にある5). どこまで報告 率を高めればよいかは難しい問題であるが, 報告 率を高めることは各国でも課題となっている. 各 国はそれぞれ特徴あるシステムをもっているが, さらに改善すべくさまざまの努力がなされてい る.

日本のシステムはモニター施設報告と企業報告 の 2 本立てであるが, 最近の状況からみても企業 に負うところが大である点は, 企業から FDA へ の報告を主とする米国と類似の状況にあると考え られる. 英国の “Yellow-Card System” は行政と の関係をもつ時期もあったが, 企業との関係はも たず，医師を主とする医療従事者からの報告が中 心となっている。どのシステムをよしとするか, 一概にはいえないが, 医療社会, 行政, 企業が協 力する姿を理想とするなら, フランスの PV シス テムはその点で優れた特性をもつといえよう。報 告率が低い原因はさまざまで対策も難しいが，米 国の改善策 “MEDWatch” は医師のみならず薬 剤師その他の医療従事者からの直接報告, さらに は消費者からの報告を容易にすることを 1 つのね らいとし, 医学・薬学関連団体の協力を得た啓蒙 活動の「プログラム」として展開しつつある77. PV システムも教育・啓蒙を重視しており, 報告を義 務とすることが報告促進にどれ程の効果をもつか はわからないが, 制度の整備とともにシステムの 理解を広め, 教育・啓蒙することには大きな意義 があると思われる。

各国がなんらかの形でシステムの中心に報告を 集中することは当然であるが, 地域分散型の情報 収集法をとり, 処方・調剤その他の医療活動を行 う人久に情報を提供する形の双方向性を組み合わ 
せる点は, PV システムの優れた特徵であり, 教 育・啓蒙にも結びつこう。個人情報の機密化と情 報公開のバランスにも配慮がみられる，企業との 関係を保ちつつ行う「審査」も特徵的であり, 我久 への説明では, 有効性と QOL を考えたリスク・ベ ネフィット関係，および代替薬を考慮して対策を 決定することを強調しており，印象に残った。

安全性確保のためには, 自発報告とともに注意 の喚起, 警告, およびその基礎となる情報を医療 社会全体に伝達しなければならないが, 医薬品庁 がその責任をもち, 学術的公表の基準を定めてい ることも PV システムの特徴であり, 処方者など からの質問に随時答える仕組みは治療中の問題へ の対処に有効であろう.

症例ごとの因果性判定は臨床薬理学と毒性学の 知識, および臨床経験と熟練を必要とし, 早期に 問題を発見して注意を喚起するためには適切な判 定が不可欠である. 判定法として用いられる「判 定樹木」や「アルゴリズム」はフランスの伝統で あり, PV システムでは規定 (compulsory) の方 法を定めている ${ }^{11)}$. 医薬品の使用中または使用後 に発生し，因果性を問わない有害事象を “adverse event (AE)”, 因果性ありとする副作用を “adverse reaction (ADR)”とする定義は最近の 諸国に共通で, PV 基準8)でも用語集に記載してい る。しかし用語集を除くと「AE」はほとんど使わ れず，「ADR」を多用することの背景には，フラン スでは個々の因果性判定を重視する歴史があると 考えられる. ADR は「副作用」と訳すべきかもし れないが，報告の時点では因果性は未判定である 事情を考慮して本稿では「有害事象」を多用し， 有用事象・副作用という表現も併用した。

以上, システムを構成する要素と役割が整然と 整理されていることが PV システム全体の特徵で
あり，自発報告制度をより有効なものにするため の参考になると考え, 概要を紹介した. 我々の訪 問を快く受け入れ, 有益な情報を提供してくだ さった PV システムの皆さんに感謝する.

\section{文献}

1) Rich ML, Ritterhoff RJ, Hoffman RJ. A fatal case of aplastic anemia following chloramphenicol therapy. Ann Int Med $1950 ; 33: 1459$ 67.

2) McBride WG. Thalidomide and congenital abnormalities. Lancet 1961 ; Dec 16:1358.

3) Osgood EE, Ore O. Hypoplastic anemias and related syndromes caused by drug idiosyncrasy. JAMA 1953；152: 816.

4) 津谷喜一郎. Pharmacovigilance とは何かーヨー ロッパのドラッグモニタリングの動向と日本の臨床 試験一. 薬理と治療 $1995 ; 23: 41-54$.

5）楠 正. 薬剤疫学の歴史と現状および今後の課題. 薬剤疫学 $1996 ; \mathbf{1}: 3-12$.

6）久保田潔。我が国に㧍ける PMS の将来へ向けて. 薬剤疫学 $1996 ; \mathbf{1}: 79-86$.

7）津谷喜一郎, 渡辺素子, 手塚 二, 櫻井靖郎, 佐野 毅. FDA-MEDWatch 訪問記. 薬剤疫学 $1996 ; 1$ : 131-40.

8) Agence du Médicament, France: Good Pharmacovigilance Practices. 1994 Dec. (English draft)

9) Decree number 95-278 concerning pharmacovigilance exerted on human use and amending the Public Health Code. March 13, 1995. (English draft)

10) International Reporting of Adverse Drug Reactions. Final Report of a CIOMS Working Group. Council for International Organizations of Medical Sciences, Geneva, 1990.

11) Official Bulletin of the Ministry of Health $84 / 50$, January 1985.
投 稿受付：1997 年 7 月 15 日 第 2 稿受付：1997 年 8 月 4 日 掲載決定: 1997 年 8 月 8 日) 